\begin{tabular}{|l|l|}
\hline Postprint Version & 1.0 \\
\hline Journal website & $\underline{\text { http://dx.doi.org/10.1016/j.healthpol.2012.03.003 }}$ \\
\hline Pubmed link & $\underline{\text { http://www.ncbi.nlm.nih.gov/pubmed/22464591 }}$ \\
\hline DOI & $10.1016 /$ j.healthpol.2012.03.003 \\
\hline
\end{tabular}

This is a NIVEL certified Post Print, more info at http://www.nivel.eu

\title{
(De)centralization of social support in six Western European countries
}

\author{
MAdELON KRONEMAN ${ }^{\mathrm{A}, *}$, MieKe CARDOL ${ }^{\mathrm{A}}$, ROLAND FRIELE ${ }^{\mathrm{A}, \mathrm{B}}$ \\ ${ }^{a}$ NIVEL (Netherlands Institute of Health Services Research), PO Box 1568, 3500 BN Utrecht, The \\ Netherlands \\ ${ }^{\mathrm{b}}$ Tilburg University, Faculty of Social and Behavioural Sciences, Scientific Centre for Care and Welfare, \\ Tilburg, The Netherlands
}

\begin{abstract}
A B S T R A C T
Introduction: Participation of disabled or chronically ill persons into the society may require support in the sense of human or technical aid. In this study we look into the decision making power of governments and the way citizens are involved in these processes. Decision mak-ing power can be political, financial and administrative and may be organized at national, regional or local level. Methods: This is a cross-sectional descriptive study of the decision making power in Belgium, France, Germany, the Netherlands, Sweden and the United Kingdom in 2010. We focused on acts and regulations for human and technical aids and for making the environment accessible. Results: Several acts and regulations were identified in relation to social support. In the Netherlands and Sweden social support was mainly organized in one act, whereas in the other countries social support was part of several acts or regulations. Citizen's voice appeared to be represented in boards or advisory committees. Descriptions of entitlements varied from explicitly formulated to globally described. Conclusions: The level of decision making power varies between the countries en between the types of decision making power. Citizens' participation is mainly represented through patient associations. Countries with strongly decentralized decision making make use of framework legislation at national level to set general targets or aims.
\end{abstract}

\section{INTRODUCTION}

People with disabilities or chronic conditions who live in the community often experience barriers to fully participate in the society. Participating in society means that one can visit family and friends, go to public facilities and join sport or social clubs. People with functional limitations may need assistance to perform these activities, for instance by providing an adequate wheelchair, facilities for transportation from A to B, access to public buildings, etc. We define social support in this paper as the formal, informal or technical assistance people receive for participating in the society, i.e. outside the home. Consequently, home care in the form of personal care, nursing care or domestic aid in the home is excluded from the definition. Although there is a vast amount of literature dealing with home care, little information is available about the organization of social support. To participate in society, different forms of support may be required: personal support in the sense of human support (accompanying disabled persons), support in the sense of technical devices (for instance in the form of an adequate wheelchair or adapted transportation), or adaptation of the environment (accessibility of public buildings etc.). For each type of support, we will 
describe the formal organization in the sense of acts and regulations. We focus on the way governments and citizens are involved in the formal organization of social support and we describe the way in which entitlements of citizens for formal or technical support are formulated.

The aim of this study is to describe the regulation of social support, for which we formulated the following research questions:

1. What acts and regulations concerning social support exist in the countries included in our study;

2. What is the role of the government in the decision making concerning these acts and regulations;

3. Which type of decision making takes place at what governmental level?

4. What is the role of citizens in the decision making pro-cess?

5. Are private organizations involved in decision making for social support?

6. Are entitlements for social support described explicitly (defining the service or the amount of money available for the service) or broadly (giving a global description of the entitlements without defining services or amounts of money)?

\subsection{The role of the government}

Governments have broadly two options to control professional support. Firstly, via a model of equal access, implying that all citizens have the same right on social support in the case they need such support, based on the level of their disability. Secondly, governments may choose to provide tailor-made solutions for individual citizens, implying that the situation of the individual is leading in receiving the support needed. Not only the level of disability but also other factors in the living conditions of the disabled person will be taken into account. We will elaborate this in the next sections. The public provision of social support may be regulated at national level (centralized), regional level or at local level (decentralized). The general idea behind decentralization is that at local level there is more knowledge about the circumstances and needs of the local population, which should lead to better services [1-6], that are organized more efficiently [5] and lead to a better account-ability [7]. However, there may be unexpected and even negative effects [8-10], such as an uneven geographical distribution of financial, human, and supply resources; local governments may pursuit their own specific interests, making it difficult to establish and achieve national priorities and in practice the public appears to have less influence in decision making and assessing priorities as expected [6,11]. Centralization, on the other hand, has the advantage of equal rights for everyone, but may have costs in the sense of decreased accountability [12] and may result in a lesser fit between individual needs and provision. According to Saltman and Bankauskaite [10] and Robinson [2] decentralization consists of three distinct concepts: political, financial and administrative decentralization. Decentralization of political power implies that local governments may formulate their own policy, resulting in more choice for citizens, less bureaucracy and more accountability, since local governments have a short distance to the citizens. The concept of financial decentralization concerns fund-raising and expenditure decisions. In a financially centralized system, the national government levies taxes and decides on the budget for social support. In decentralized systems, local governments have the power to raise funds and decide on budgets. The concept of administrative decentralization addresses the provision of care. This may include the (organization of) actual provision of social support or carrying out needs assessments. For needs assessments, rules may be set by higher governments (politically centralized), but the actual decision whether a person is entitled to support may be set at local level (administrative decentralization). Robinson includes also functions that are transferred to geographically distinct administrative units, i.e. organizations at local level that are created to provide social support in a way that is decided by a higher level government [2]. Saltman and Bankauskaite [10], restrict the validity of the above concepts of decentralization to tax based health care systems. For Social Health Insurance systems, the model is complicated by the introduction of private actors and public control and supervision of these private actors. Robinson [2] also points to the increasing importance of the private sector in health care provision. Privatization can also be viewed as a kind of decentralization [13], governments may decide to delegate decision making to private organizations, this can occur for all three concepts. In the health care sector, at political level, privatization is most likely toward quasi non-governmental organizations, where accountability is maintained through contracts that formulate explicit performance targets [14]. At financial level, private organizations may collect financial sources from citizens (clients) and/or governments and may purchase care for their clients, as in private insurance companies in a social health insurance system. At administrative level, governments may outsource the actual care delivery to private organizations, as is the case for home care in The Netherlands. Social support is often organized differently from health care, but both systems have in common that they can be considered as part of the social welfare state. Although there is no specific 
literature on the role of the government in social support as defined in this study, Genet et al. [15] identified similar roles of governments in home care compared to health care. This implies that governments are involved in the governance of both health care and home care. Home care, according to Genet et al. [15] can be divided in home health care and social care. The latter refers to social care and support in the home. We assume that for social support outside the home, as defined in this study, similar functions of governments may apply com-pared to social support in the home and thus we think the model of Saltman and Bankauskite can be applied as well. Furthermore, social support may be decentralized to private organizations as well. Thus, the model of Saltman and Bankauskaite should be extended with decentralization to the private sector to be valid for social support. Also, there is some hierarchy in the three types of decentralization. If political decentralization takes place, it is plausible that also financial and administrative decentralization are in place and if financial decentralization is in place, also administrative decision making is likely to be at local level (see Fig. 1). If political decision making is decentralized, central governments may want to set general boundaries in which lower governments may make more explicit regulation. These broad boundaries are often described in framework legislation. Rothgang et al. [16] pointed out that this function exists as role of the central government in healthcare and we think this may also be the case in social support.

\subsection{The role of citizens}

When decision making is decentralized to local levels, accountability is expected to increase [7]. Thus, we expect that in these cases citizens will be explicitly involved in decision making and that citizen representation is more explicitly organized in the sense of participation in advisory boards or committees.

\subsection{Entitlements for social support}

Since the idea behind decentralization is that more tailor made solutions can be made, we hypothesize that in decentralized systems entitlements are broadly described in general terms, whereas in central systems entitlements are explicitly formulated (for instance as predefined amounts of money or predefined services for specific levels of disablement). In this study, political decision making refers to decisions on legislation concerning social support, on eligibility criteria and on the organizational structure of social sup-port. Financial regulation refers to decisions on which funds are available for social support and how these funds are raised (via taxation, social insurance or private contributions). Administrative decision making refers to applying the eligibility criteria in the case of individual needs assessments and the individual assignment of services and organization of services.

\section{METHODS}

\subsection{Choice of countries}

We included Belgium, Germany, France, The Netherlands, Sweden and the United Kingdom in this study. The selection of these countries was based on the following considerations. In these countries, the public opinion is positive toward professional care (on or above the European average) and citizens think that long-term care should be financed via public authorities or social security (above the European average) [17]. This implies that there is in general public support for formal care and thus we expect that there is also public support for formal regulation concerning social support. A second reason was that these countries have a comparable level of wealth, implying that differences in the organization of social support are not primarily the result of differences in financial resources. A third reason was rather practical: national language skills are needed, since social support legislation is seldom published in other than the national language (except for Sweden, where many documents in the English language are available). The countries will be discussed in alphabetical order. The countries differ in the way they have organized their health care systems, but since social support is generally part of social services and not of health care services, we do not think this limits the comparability of the countries.

\subsection{Data collection}

This report provides descriptive cross sectional study of the governance of social support. Since little international comparative information is available and peer reviewed journals seldom publish about this type of support, we used the 'snowball method' for finding the appropriate information. For each country, we gathered formal policy papers and acts in which social support issues were described. Furthermore, websites of governments, public organizations and organizations of patient representatives were visited in order to gather information on regulations, entitlements and patient participation. The situation described 
for each country concerns the situation that was valid in 2010. For the UK, the situation described here mostly concerns regulations valid to England, Wales and Scotland. If regulations vary among these regions, the English situation is described.

\section{RESULTS}

\subsection{Belgium}

In Belgium, most of the social support regulation is de-egated to the regional level (there are three regions in Belgium: the Flemish region, the Walloon region and the region of Brussels-Capital). The aim of the devolution policy was to improve responsiveness of services by bringing decisions that have an impact on the population's health closer to the population level. However, the downside of this measure was, according to Corens, the increased potential for coordination problems between the different decision centers [18] (p. 9). As an example, we describe the organization of social support in the Flanders community. The main aim in Flanders is to promote active participation in society for every citizen. Social support is provided by the Flanders Agency for Handicapped Persons (Vlaams Agentschap voor Personen met een Handicap, VAPH), which was introduced in 2006. The VAPH is the counter for handicapped people for aids and (house)adjustments; subsidizes care in kind from professional organizations; and provides personal-assistants budgets. Handicapped persons can employ these assistants in order to be able to live in their own house and includes assistance at school or work. The budget for personal assistants is limited, as a result of which an allocated application may not result in providing the budget actually. The Flemish minister establishes priority rules every year. The VAHP also promotes accessibility of public buildings, public transportation and information. The accessibility of public buildings is regulated in the new bylaw Urban Accessibility (Stedenbouwkundige Verordening Toegankelijkheid) that was introduced in March 2010. This bylaw was introduced by the regional government.

\subsubsection{Roles of the governments}

The political, financial and administrative decision making concerning social support is delegated to the regional level. In the case of the Flanders region, the administrative decision making is delegated to the Flanders Agency for Handicapped Persons, a regional organization. This institute is financed by the Flemish regional government. The entitlements for handicapped persons for services and technical aids are established by the Flemish government and described in a rather detailed way. There is a reference list (Refertelijst) that describes for functional limitations of each part of the body what services or aids can be received and for what amount [19,20]. Final decisions concerning needs assessment are provided by one of the five Provincial Evaluation Committees. These committees are independent from the VAPH and the members are appointed by the Flemish government. Thus, administrative decision making concerning the needs assessment is further delegated to the provincial level. Some regulation has remained at federal level, such as the application for a disabled parking permit.

\subsubsection{Roles for the citizens}

Representatives of patients' associations for disabled people and their relatives are involved in the management of VAPH [21]. The advisory council (Raadgevend Comité) is the most important advisory body of the VAPH and consist of representatives from persons with a handicap, but also from organizations providing services and facilities and employees of these organizations. The council provides advice when asked for but also on its own initiative. The council is in place for a four-year period [22].

\subsubsection{Entitlements for social support}

The entitlements for aids like wheelchairs are described explicitly in the reference list (refertelijst). The reference list provides the maximum financial compensation for the combination of disability and type of aid. For more complex or more expensive aids, a special, ample motivated request can be made to the Committee for Special Social Security (Bijzondere Bijstandscommissie). Applications for a Personal Assistant Budget (PAB) should be addressed to the VAHP, where a multidisciplinary team assesses the necessary assistance. PABs varied from 8845 to 41,278 euro on a yearly basis in 2009. Personal assistants can perform social support services besides other forms of personal care. The total budget for PABs is limited, when the overall budget is spent, new applications are not rewarded anymore. Summarizing, in Belgium the main part of social sup-port is delegated to the regional level. The regional level has financial, 
political and administrative power. Administrative power is further delegated to a regional institute for the provision of support and to provincial level institutes for the decisions concerning needs assessment. Entitlements for citizens are explicitly described in a detailed manner. Citizens may provide advice at the level of administrative decision making. If standard options do not fit for an individual citizen, there is an option for tailor made solutions via the Committee for Special Social Security. Municipalities are not involved in social support for disabled persons.

\subsection{Germany}

In Germany, the regulation for aids for handicapped people is written down in the federal legislation. The fifth social code (Sozialgesetzbuch V) describes who is entitled to obtain these aids. The actual implementation is dele-gated to the sickness funds. People with disabilities have to apply for aids at their sickness fund, who evaluates the appropriateness of the application. There is a list of aids

(Hilfsmittelverzeichnis) that will be compensated by the sickness funds. Financing takes place via the social health insurance system. For care for disabled people, the ninth and twelfth social code (Sozialgesetzbuch IX and XII) describe the right on participation in the society. Besides the in-kind provision of services, citizens have the options to apply for a personal budget (laid down in the ninth social code). This personal budget may apply to one type of care only, but can also include several different services from different social systems (e.g. health care, assistance for labor participation, nursing care) combined in one bud-get [23]. A special act regulates access for the disabled into society, the Disabled Equality Act

(Behindertengleichstel-lungsgesetz). The act regulates that disabled should have access to and should be able to use buildings, roads, machines, cell-phones and internet sites in the same way as healthy people. All (newly created) human made environment should apply to the requirements of this act. A national ambassador (Beauftragter der Bundesregierung für die Belange behinderter Menschen) is appointed to see to the execution of this act. No financial or personal allowances are associated with the act, although disabled persons or their representatives (e.g. patient associations) have the right to appeal.

\subsubsection{Roles of the governments}

The federal government establishes the list of aids and establishes the rights of disabled persons in the social codes (Sozialgesetzbücher V, IX and XII). The execution of social support is delegated to the sickness funds in the case of aids and the execution of the long-term care insurance (Sozialgesetzbuch XI) and toward the national ambassador for observing the execution of the Disabled Equality Act. In the case of human aid, the execution is delegated to the statutory long-term care insurers.

\subsubsection{Roles for the citizens}

There seem to be no explicit responsibilities for citi-zens in the policymaking process and the organizational structure concerning the list of aids in Germany. At the level of the Länder and municipalities often a Committee for Disabled (Behindertenbeirat) is in place, that advises, if necessary on their own initiative, the (local) government on disability issues. These committees are regulated in regional (Länder) or local (municipal) legislation and address the issue of the development of a society with equal chances for disabled and non-disabled persons. Members of these committees are mostly representatives of organizations for the disabled, but may in some cases also be independent persons who have a handicap or representatives of political parties may participate.

\subsubsection{Entitlements for social support}

Wheelchairs are provided in-kind. The sickness fund or the organization where the sickness fund rents the wheelchair keep the ownership of the wheelchair. Adaptations that are considered not medically necessary have to be paid by the citizen. For example, for an electric wheelchair with a speed above $6 \mathrm{~km}$ per hour, the citizen should pay the extra costs out-of-pocket. Wheelchairs should be prescribed by a physician. The list of aids (Hilfs-mittelverzeichnis) should be seen as advice to the sickness funds [24,25]. People can decline the offer of a specific wheelchair if that wheelchair does not meet their needs. The personal budget, if applicable, should not exceed the cost of an in-kind provision. The budget is earmarked, in the sense that the budget holder should justify the expenditures. The height of the budget depends on the need of the individual. However, the care insurers often pay lower amounts compared to the in-kind provision and thus use the personal budget as a form of cost containment. This is not against the law [26]. The amounts people receive for their personal budget or the amount in which in-kind care is compensated for depends on the 
level of disability. There are three levels of disability, level 1 is the lowest with at least $1.5 \mathrm{~h}$ help needed, with more than once of week help needed with instrumental activities of daily living, such as shopping or transportation (which includes our definition of social support). Level 3 is the highest level, for persons who need care around the clock [27]. Depending of the level of disability a maximum amount is available from the long-term care insurance. The amount covered by the long-term care insurance is not enough, a substantial out-of-pocket payment is still required [28]. Summarizing, for Germany, political power is at federal level. At this level, a list of aids is set and the maximum amount for long-term care benefits is established. Administrative power is delegated to the sickness funds and the long-term care insurers. At the income side, financial power is the responsibility of the sickness funds and the long-term care insurers. However, since the list of aids is set at federal level, the expenditure side can hardly be influenced by the sickness funds, although the list is considered to be an advice according to the National Association of Statutory Health Insurance Funds (GKV-Spitzenverband) [24]. At the level of Länder and municipalities, representatives of disabled organizations have advisory powers through the committees for disabled. For human aid, persons can choose for in-kind provision or a personal budget, where the amount of money available for the personal budget is often lower than for the in-kind provision. The decision for this is made by the care insurers.

\subsection{France}

In France, social support is for a large part regulated by the Handicapped Act (Loi Handicap), that came into effect in 2005. In this act the fundamental rights of handicapped people are described. There are three important elements in the act concerning social support. These are: the right of compensation of the handicap at home and in society in the sense of help by humans, technical devices or assis-tive animals, and adaptation of the home or car; the right on access to public buildings and transportation; and the creation of Maisons départementales. Elderly and handi-capped persons can go to these Maisons for: information and advice on long-term care institutes and services; a per-sonal plan in order to live independently and participate socially and; needs assessments and claim evaluations [29]. Financial support for the right to be compensated for the handicapped is provided in two age-differentiated financ-ing schemes, that provide financial contributions to obtain, among others, social support. For persons younger than 60 years of age, the scheme for medico-social support is called: Regulation concerning Compensation for Handicaps (Prestation de Compensation du Handicap, PCH). This scheme was introduced in 2006 and is part of the Loi Handicap. The other scheme, for persons aged 60 years and over, is called the Personal Independence Allowance (Allocation Person-nalisée d'Autonomie, APA), which is part of the Code of social action and families (Code de l'action sociale et des familles) [30]. This scheme came into effect in January 2002. It pro-vides financial support for people aged 60 years and over who are dependent of care. APA is both for elderly people living at home and living in institutes. Another relevant part of the Code of social action and families is the compensation allowance (la prestation de compensation), which regulates allowance for housing adaptations, adaptation of cars, tech-nical aids and assistive animals [31] and the complément de ressources, which provides additional benefits that allows disabled people living in independent housing, and under certain conditions, to fund any adjustments required by the disability.

\subsubsection{Roles of the governments}

The APA and PCH schemes are financed in two ways. At national level by the National Fund for Solidarity for Auton-omy (Caisse Nationale de Solidarité pour l'Autonomie, CNSA) The National Fund establishes the conditions for financial compensation and the maximum monthly compensation for applicants of APA and PCH. The National Fund pays the departments for the organization of care within the scope of APA and PCH. The budget of the National Fund is based on contributions from the state (taxbased) and from social security (premium based). The National Fund attributes to approximately $33 \%$ of the costs of APA. The distribution of the National Fund contribution over the departments is based on criteria, such as demographic characteristics and wealth of the department [32]. For the PCH-scheme the National Fund sets a fixed financial contribution for each department. In 2006-2008 this contribution exceeded the real expenditure on $\mathrm{PCH}$, because the appeal to PCH by dis-abled citizens evolved much slower than was anticipated, persons who already had an allowance under the old reg-ulation (the Allocation compensatrice pour tierce personne, ACTP) were allowed to continue this upon their wish. Many did so, because the financial compensation under the new regulation was difficult to predict beforehand, whereas the compensation under the old regulation was clear [33,34]. At regional level, the French departments also contribute financially to APA (and in the future also to PCH). At depart-mental level applications for 
support are evaluated and decided upon. The Maisons départementales have the function of a one-stop counter. People file their claim at the Maisons départementales. On behalf of the Maison, the Commission of the rights and autonomy of handicapped persons (La commission des droits et de l'autonomie des personnes hand-icapées, CDAPH) carries out the needs assessment, which results in a personal plan for compensation of the hand-icap. The CDAPH uses the application of the handicapped person and the assessment of an interdisciplinary team to decide upon the eligibility. This multidisciplinary team consists of professionals (both medical and social) that are able to evaluate the needs of the disabled person. The team draws an individual plan of compensation for the disability of the applicant. The final decision of the CDAPH is reached through voting by its members [35]. The CDAPH also decides on applications for the compensation allowance and the additional allowance. The maximum amount available for the additional allowance is established at national level. All the contributions discussed here are financial allowances that disabled individuals can use to buy care or technical compensations.

\subsubsection{Roles for the citizens}

Representatives of associations of handicapped persons are member of the council of the National Fund (CNSA). The council sets the main policy lines [36]. The Commission on the rights and the independence of handicapped persons (La Commission des droits et de l'autonomie des personnes handicapées), in which associations of handicapped persons are represented, represents, among others, citizens within the Maisons départementales [37].

\subsubsection{Entitlements for social support}

The personal plan for compensation covers the need for human and technical aids, housekeeping, transportation and specific or exceptional aids [38]. PCH consists of five fields of entitlements: (1) Human help, (2) technical aids, (3) housing adaptations, adaptations of cars and extra costs of transportation, (4) contributions for special or exceptional expenditures and (5) assistance and guide dogs. The amount of financial support under APA is based on the personal situation of the elderly person taking into account the degree of dependence and the income of the applicant. The allowance takes the form of a financial contribution and should be used to finance (part of) the personal care plan. Financial compensation can be obtained firstly via the health insurance, but the amount is limited to 5200 euro (in 2011) [39]. Additional funding, if necessary, may be obtained via PCH. Summarizing, in France, political and financial governance are mainly at national level: clearly established entitlements in the sense of maximum amounts are set at national level. Departments also contribute financially, and thus contribute to financial governance in the sense of raising funds, but they have no influence on the expenditure site, since entitlements are regulated nationally. Administrative power is delegated to the departments, where the Maisons départementales evaluate the applications of their citizens through the Commissions on the rights and the independence of handicapped persons.

\subsection{The Netherlands}

The Social Support Act in the Netherlands encloses both the area of well-being and welfare policy. The aim of the act is to achieve participation of all citizens to all facets of the society. According to the act, people should be compensated for their handicap to be able to participate in society independently. The act is based on a hierarchy of support systems: if people need support, they first should try to solve this within their own social network. If the support provided by one's own network is not enough or not possible, people can turn to the municipality [40]. Further, the Social Support Act should make it easier to provide tailor-made services on a local level. The act is expected to allow for more innovation and more efficiency because officials are closer to the population and know the field. Besides, the act is expected to enhance civic participation [41]. The idea is that this will lead to greater flexibility and a more demand-driven approach [42]. Citizens can apply for sup-port at the Social support window, situated at the town hall. Many municipalities provide a choice between providing services or aids in kind or providing a personal budget, making it possible for citizens to buy their own support or aids. The municipality is also obliged to organize adequate transportation at local level for persons who cannot travel with public transportation. For traveling over longer distances, a private national organization takes care of the organization. This organization is given a concession for a few years.

\subsubsection{Roles for the government}


The role of the central government is taking care of preconditions through framework legislation and moni-toring the implementation. To finance the activities under the Social Support Act, municipalities receive a budget from the central government. However, the budget is not earmarked, implying that municipalities can set other pri-orities in spending the budget, even outside the scope of the Social Support Act. The municipalities are responsi-ble for delivering and paying the social support for people with a disability. Thus, for the expenditure side, financial decentralization is achieved. On the financing side, munic-ipalities may decide upon co-payments for their citizens. They are free to establish the height of these co-payments. Within the framework of the act, municipalities have room to make their own choices with regard to participation of citizens and provision of care and support. As such, they have gained both political and administrative power. Dif-ferences between municipalities are considered acceptable as long as the nationally set targets are achieved.

\subsubsection{Roles for the citizens}

The Social Support Act forces municipalities to involve citizens in the execution of the act. Almost all municipal-ities have installed client councils that have the task to advice the municipality on policy developments, to sig-nal problems in the execution of the act, and to formulate points for improvement. The representation of people with a physical handicap (participating in $84 \%$ of the coun-cils) and elderly (in $90 \%$ of the councils) is rather high. Representatives of patient organizations consider their representation in these councils as rather satisfactory [43]. However, not all groups to which the Social Support Act is targeted are sufficiently represented, for instance persons with intellectual disabilities are underrepresented [43].

\subsubsection{Entitlements for social support}

The entitlements of citizens are based on the fact that people have the right to be compensated for their disability or handicap. Explicit entitlements are not described in the act. Also at municipal level, entitlements are mostly described in a broad way: people should be compensated for their handicap. If an individual asks for support, the situation of this individual is evaluated. Some municipalities make use of independent assessment organizations for assessing the need of a person, other municipalities have appointed a municipal official as social-support act advisor. There are no descriptions of entitlements in official documents, the emphasis is on evaluating each individual situation. Only for long-distance transportation, national entitlements have been settled: a maximum number of kilometers that may be traveled by adapted transportation (wheelchair taxis for instance) for a low budget. There are two kilometer budgets, one for persons who can travel by train, and one for those who cannot. Freedom of choice for people with a disability and the elderly is stimulated by the introduction of a personal bud-get. Citizens can apply for social support services in kind or for a personal allowance with which they can choose and purchase the support or technical aid themselves. Summarizing, the national governments sets the framework for the Social Support Act. Within this framework, municipalities have gained political power to a major extent. They are free to establish their own priorities, as long as they fit in the boundaries of the national policy targets. The municipalities also have gained administrative power: they are free to organize the daily practice as they like, although the act prescribes that wherever possible, municipalities should cause social support to be provided by third parties. Financial decentralization is established at the expenditure side, and partly at the fund raising side in the form of co-payment from applicants of services. Social Support is besides co-payments funded via a grant into the municipality fund, the height of which is decided by the national government. Entitlements for citizens are describe in broad way: municipalities should compensate citizens for the consequences of their handicap in participating in the society. No explicit entitlements are described in the act.

\subsection{Sweden}

Decentralization processes in Sweden started by the end of the 1970s, to reduce the negative effects of the bureaucracy in health care. The process of decentralization started as an experiment in some of the county councils. The idea was that local politicians could be more responsive to local needs and priorities [44]. This process spread quickly all over the country, and in the beginning of the 1980s, a large decentralization process started in the Swedish health care system [45]. In 1982 the Social Service Act came into force. The Social Service Act was meant to be an implementation of the view of equal health for all: everyone who needs care should be able to live at home as long as possible. People with a chronic illness or disability and 
the elderly had priority [44]. Handisam, the Swedish Agency for Disability Policy Coordination aims to ensure that policymakers at various levels in society realize the benefits of an accessible society where everyone can participate equally. Handisam has been tasked by the Government with developing methods for monitoring the efforts made by the municipalities to promote accessibility.

\subsubsection{Roles of the governments}

The national government legislates and formulates guidelines for care of the elderly and who is to provide the various services involved. Monitoring of the process is delegated to an independent national organization, called Handisam. The County Councils and municipalities operate fairly autonomously from the national government. For example, they can impose taxes and formulate priorities for special groups [46]. Municipalities have financial responsibility and should organize long-term care for the elderly and the disabled. Disabled people are entitled to receive support not only under the Social Service Act but also under special legislation: The Act Concerning Support and Service for Persons with Certain Functional Impairments provides for support for items such as personal assistance and daily activities. Most tasks under this act are the responsibility of the municipalities. The costs of particular social services vary widely across the different municipalities [47]. The system responsibility of social services for people with disabilities rests with the regional government.

\subsubsection{Roles for the citizens}

In 2008, the Minister for Elderly Care and Public Health emphasized that she wanted to promote the responsi-bility and empowerment of the individual in order to create a stronger civil society. "Truly effective public health efforts are based on responsibility being shared jointly between the public and nonprofit sectors and the individ-ual” [48]. The Swedish Association of Local Authorities and Regions has made a recommendation for municipalities (and county councils) to have a disability council, consist-ing of representatives from the municipality, the disability organizations and other stakeholders in the municipalities. Almost all of the 290 municipalities in Sweden have dis-ability councils (94\% in 2008) with representatives from disabled associations. Besides, Handisam has an advisory board in which disabled and patient associations are repre-sented. Furthermore, a delegation of representatives from the disability organizations and state secretaries from rel-evant ministries meet four times a year. Many government organizations have contacts with disabled associations to ensure that their activities, premises and information are accessible for disabled persons.

\subsubsection{Entitlements for social support}

People who need help to support themselves in their day-to-day existence have the right to claim assistance if their need "cannot be met in any other way". A case man-ager employed by the municipality carries out the needs assessment. Charges for the care of the elderly are levied under the Social Services Act. Within the framework of the act, each municipality decides its own system of charges and the specific charge payable by the individual. Within this act all elderly have the right to receive health care ser-vices and welfare, which guarantee a minimum quality of life. Local communities are responsible to provide this care [49]. Assistive devices for the disabled are provided by the municipalities under the Health and Medical Act [49,50]. Entitlements are not specified in detail: the municipality should ensure that persons that encounter difficulties in their everyday lives due to physical, mental or other reasons, are enabled to participate in the community and to live like others [51]. Summarizing, in Sweden, the governance of social sup-port is mainly delegated to the municipal level. This is the case for political, financial and administrative power. However, at national level the framework is set in which the municipalities may develop their policies. The act does not describe explicit entitlements for citizens. The level of decentralization of responsibility for social support is com-parable with the Netherlands.

\subsection{UK}

The main regulation concerning people with disabilities and their participation in society is laid down in the Disability Discrimination Act. This act came first into effect in 1995 and since October 2010 became part of the Equality Act. This latter act provides a legal framework to protect the rights of individuals and advance equality of opportunity for all and brings together all legislation on discrimination. In this act there is a special section on disability, in which is described that if a disabled person experiences significant disadvantage compared to non disabled persons, this disadvantage should be, as far as it is reasonable, 
eliminated. This statutory code of practice describes in detail what are the responsibilities for public authorities in dealing with disability equality. The costs of this should not be levied on the disabled person. Existing resources should be applied in such a way that the code of practice is met. Public authorities should publish both their policy (Disability Equality Scheme) and an annual evaluation of what has been reached in the sense of disability equality [52]. If a public authority does not comply with the code, the Disability Committee has the power to challenge this authority by means of a claim to a Court. The act also has a special section on public transportation for disabled persons and on adjustments of let dwelling houses for disabled per-sons. The Equality and Human Rights Commission has the task to ensure that people are aware of their rights and how to use them and to enforce laws that are already in place. Within the Equality and Human Rights Commission a special committee is dedicated to disability: the Disability committee. This committee was considered necessary by the Government because of the highly distinctive nature of disability equality law, in particular the duties to make reasonable adjustments, and the complex technical and ethical issues associated with promoting disability equality. The Disability Committee has decisionmaking powers in relation to those matters which solely concern disability, and the Commission must seek the advice of the Committee on all matters which relate to disability in a significant way [53]. Wheelchairs are provided by the National Health Ser-vice (NHS) free of charge [54]. People who would like to choose their own wheelchair can obtain a voucher of the NHS and buy a wheelchair themselves. Local health authorities run Wheelchair Services where patients may obtain a wheelchair after referral by a health professional or in some cases also by self-referral. Eligibility criteria may vary by Wheelchair Service $[55,56]$. Under the Social Security Contributions and Benefits Act, people who are under the age of 60 and who need care or have mobility problems can apply for a tax-free disability allowance, that consists of a care component and a mobility component, the latter can be used to finance a (more expensive) wheelchair, scooter or car adaptations (see [57]). Applications are evaluated by local Disability Benefit Centres. Charities (such as the Motability scheme) help disabled people in choosing and buying adapted cars, wheelchairs and scooters. People of 65 years and over may apply for an attendance allowance, which comes in two different weekly rates [58]. For social services, also direct payments are available. These cash payments offer individuals who are assessed as needing community care services the opportunity to arrange their own personalized care, rather than receiving services directly provided by a local authority [59].

\subsubsection{Role of the governments}

Regarding issues that fall under the Equality Act, political decision making is at central level. Financial and administrative decision making is delegated to the municipal level. There is no specific budget designated to these issues at central level, municipalities have to execute the act, while using existing resources. For the Disability Living Allowance and the Attendance Allowance, the administrative decision making is delegated to local Disability Benefit Centres, that reside under the Department for Work and Pensions. Political decision making is at national level, where entitlements are described in the Social Security Contributions and Benefits Act. For aids, such as wheelchairs, the administrative decision making is decentralized to the National Health Service and to the citizens, who can use their financial allowances to buy aids from charities (such as the Motability Scheme).

\subsubsection{Roles for the citizens}

The Equality Act requires the involvement of disabled persons in the policy process [52]. Local authorities are free in the way they organize this involvement and may involve existing disability organizations of forums or, where these do not exist, special forums can be set up, as long as the involvement is focused, efficient, influential, and transpar-ent. As a result, the organization of disability representation varies among municipalities. At national level, the Dis-ability committee represents disabled persons interests: members have their roots in diverse disability and patient associations.

\subsubsection{Entitlements for social support}

Wheelchairs can be provided by the NHS, through Wheelchair Services, where wheelchairs are delivered in kind or can be funded or part-funded using a voucher scheme in the case a disabled person chooses an alterna-tive of the wheelchair that is assessed. The voucher reflects the value of the originally assessed wheelchair and the dis-abled person pays the difference. For financial allowances, such as the Disability Living Allowance and the Attendance Allowance the entitlements are explicitly described: for a certain degree of disablement, a predefined amount of money can be received. The allowance can be spent in the 
way the disabled persons thinks it is appropriate. There is no need to justify the expenditures afterwards [60]. Summarizing, for the UK, political decentralization does not seem to be applicable: regulations are estab-lished at national level. Administrative decentralization exists on the level of local councils. The local councils assess the needs of people with disabilities and decide whether an applicant is eligible for either financial or in-kind compensation. For the disability living allowance, the administrative decision making is delegated to specific regional institutes that fall under the department of Work and Pensions. Explicit entitlements, either financially or in kind are included in the regulations. According to the Equality Act, citizens should be involved in the decision making concerning making the environment more friendly for disabled persons. Local authorities are free in how to organize this involvement, but should publish their effort en results annually.

\section{DISCUSSION}

The regulations concerning participation in society for disabled persons vary widely over the countries in this study. In some countries, the regulation is part of a more comprehensive regulation that is also valid for other groups of vulnerable persons (like in Sweden and The Netherlands). In the UK, participation of disabled persons is recently regulated under the Equality Act, that contains legislation against discrimination of all minorities. How-ever, other parts of social support fall under other systems: such as the National Health Services and the social security system, In France, a national act concerning disabled people is covering most regulations concerning social support. In the other countries, the regulation is spread over several different acts. Almost complete decentralization of regulation concerning societal participation can be found in The Netherlands and Sweden (see Table 1). Both countries have decentralized almost all aspects of decision making in social support toward the municipal level. In Sweden the decentralization affects all types of powers: political, financial and administrative. In the Netherlands political and administrative power have been decentralized. Financial powers are decentralized only partly, since the central government decides upon the grant municipalities receive from the national budget, although municipalities may decide upon levying out-of-pocket payments. In both countries the decision making by municipalities have to take place within the national framework that is settled by the national government. In the other countries in our case study the decision-making is partly decentralized to the regional level, which is the intermediate level between national and municipal level. In all countries in our study, citizens have at least an advisory role in the policy making process, regardless the level of decentralization. Mostly this is regulated via committees or councils in which representatives of disabled and patient associations are represented and for most of these, there is an explicit regulation (e.g. in Germany) or recommendation (e.g. in Sweden) on how they should be organized. In the UK, where political decision making is centralized, the regulation of citizen involvement is compulsory, but there is no explicit description of how this should be organized. Committees at local level exist both in decentralized and centralized countries. Differences in the level of decentralization result in differences in the description of the entitlements for disabled persons.

\section{[TABLE 1]}

In countries with a large degree of decentralization, as in the Netherlands and Sweden, entitlements are only broadly defined in terms of compensation of impairments in order to participate in society. In the countries with a high level of centralization, entitlements much more explicitly described, as well as the conditions under which people may apply for these entitlements. This may vary from (maximum) financial allowances (France and UK) to explicit lists of appliances and aids (Belgium and Germany). Friele [61] makes in this respect a distinction between insured rights that are explicitly described and right for compensation. The right for compensation is usually less clearly defined as insured rights [61], making it more difficult for citizens to appeal. Participation in society is in Germany, France, UK and recently in Belgium also regulated via special acts con-cerning the access of people with disabilities to buildings, transportation etc. There is generally no financial sup-port directly to disabled persons or to other persons or institutions resulting from these acts, but new projects, varying from e.g. buildings to transportation to websites (in Germany) are entitled to take accessibility into account. The main message of these acts is that people with dis-abilities should be able to participate in the same way as ordinary people and that special measures for disabled that stimulate their participation (like ramps, special parking sites, elevators) is not 
considered as positive discrimination of disabled persons but as a right. Enforcement of these acts can be observed by appealing to court. In the Netherlands and Sweden, accessibility issues for buildings are regulated within the scope of the national building acts. Decentralization of decision-making powers to private organizations exists mainly at administrative level, espe-cially for aids. This is the case in Germany (by health insurers), Belgium (The Flanders Agency of Handicapped Persons), The Netherlands (transportation and some forms of personal support) and the UK (where part of the wheelchair market is covered by a charity). A special form of privatization is formed by the personal budget. Administrative decision making and some part of the finan-cial decision making (purchasing care or aids) is in that case delegated to the handicapped person or his/her legal representative. The Swedish Agency for Disability Policy Coordination (Handisam) is a private organization that does not fit into our description of private organizations. The central government has delegated the control function to this organization. Participation into society for disabled persons is in most countries organized separately from the health care sec-tor. When the health care sector is involved, this mainly concerns technical aids. Other aspects of social support fall under regulations for social security or social assistance.

\section{CONCLUSION}

In decentralized social support systems local governments have gained a large part of the decision making power, but at national level government provide the frame-work or guidelines in which the local governments have to work. In countries with a centralized system, national governments' role concerns providing detailed descriptions of who is entitled and what are their entitlements, defining categories of dependence and national reference lists for aids and support. Representatives of disabled and patient organizations seem to have an explicit role in the sense of advisory boards, regardless of the degree of decentralization. Accessibility of, for instance, buildings or information is in a few countries regulated in a special act, giving citizens the option to appeal to court if the act is not observed. Decentralized systems indeed seem to provide room for local governments to make their own policy concerning social support. This may provide opportunities for municipalities to provide tailor made services. On the other hand it may be difficult for citizens to gain insight in their entitlements. In centralized systems often explicit and detailed entitlements are described, but this leaves less room for adjusting to individual situations. In the UK and France, entitlements are explicitly formulated in the form of an allowance. The way this allowance is spent is up to the responsibility of the applicant. This may provide freedom of choice for the citizen within the financial boundaries. In Germany, the personal budget also provides such freedom, but here the recipient needs to justify the expenditures. The existence of personal budgets or financial allowances can be seen as decentralization of the administrative decision making to the individual citizen and thus may be identified as an ultimate form of decentralization to the private sector.

Competing interests

The authors declare that they have no competing interests.

\section{Acknowledgments}

The authors would like to thank the anonymous reviewers, their valuable comments have been very helpful in structuring our paper.

\section{REFERENCES}

[1] Dowley KM. Local government transparency in East Central Europe. Local Government Studies 2006;32:563-83.

[2] Robinson M. Does decentralisation improve equity and efficiency in public service delivery provision? IDS-Bulletin-Institute of Develop-ment Studies 2007;38:7.

[3] Faguet JP, Wietzke FB. Social funds and decentralisation: opti-mal institutional design. Public Administration and Development 2006;26:303-15.

[4] Lundin M, Skedinger P. Decentralisation of active labour market policy: the case of Swedish local employment service committees. Journal of Public Economics 2006;90:775-98.

[5] Rodriguez-Pose A, Tijmstra S, Bwire A. Fiscal decentralisation, effi-ciency, and growth. Environment and Planning A 2009;41:2041-62. 
[6] Milewa T, Valentine J, Calnan M. Managerialism and active citizenship in Britain's reformed health service: power and com-munity in an era of decentralisation. Social Science and Medicine 1998;47:50717.

[7] Yilmaz S, Beris Y, Serrano-Berthet R. Linking local government dis-cretion and accountability in decentralisation. Development Policy Review 2010;28:259-93.

[8] Kuhlmann S. Between the state and the market: assessing impacts of local government reforms in Western Europe. Lex Localis: Journal of Local Self-Government 2010;8:1-21.

[9] Wistow G. Decentralisation from acute to home care settings in Eng-land. Health Policy 1997;41:91108.

[10] Saltman R, Bankauskaite V. Conceptualizing decentralization in Euro-pean health systems: a functional perspective. Health Economics, Policy and Law 2006;1:127-47.

[11] Craig D. Reterritorialising health: inclusive partnerships, joined-up governance and common accountability platforms in Third Way New Zealand. Policy and Politics 2003;31:335-52.

[12] Seabright P. Accountability and decentralisation in government: an incomplete contracts model. European Economic Review 1996;40:61-89.

[13] Saltman R. Decentralization, re-centralization and future European health policy. The European Journal of Public Health 2008;18:104.

[14] Atun R. Privatization as decentralization strategy. In: Saltman RB, Bankauskaite V, Vrangbaek K, editors. Dezentralization in health care. Maidenhead: Open University Press; 2007. p. 264-71.

[15] Genet N, Boerma WG, Kringos DS, Bouman A, Francke AL, Fager, et al. Home care in Europe: a systematic literature review. BMC Health Services Research 2011;11:207.

[16] Rothgang H, Cacace M, Frisina L, Grimmeisen S, Schmid A, Wendt C. The state and healthcare; comparing OECD countries. Basingstoke, Hampshire: Palgrave Macmillan; 2010.

[17] TNS Opinion \& Social. Special Eurobarometer: Health and long-term care in the European Union. Wave 67.3, no. 283. European Commis-sion; 2007.

[18] Corens D. Belgium: health system review, vol. 9, no. 2. In: Merkur S, Jemiai N, Palm W, editors. Health Systems in Transition; 2007.

[19] BESLUIT van de VLAAMSE REGERING van 13 JULI 2001 tot vaststelling van de criteria, voorwaarden en refertebedragen van de tussenkom-sten in de individuele materiele bijstand voor de sociale integratie van personen met een handicap

[Decision of the Flemish government of 13 July 2001 to establish the criteria, conditions and reference amounts for the individual support for social integration of persons with a handicap]; 13-7-2001. p. 1-16.

[20] Beheersovereenkomst tussen de Vlaamse Regering en het Vlaams Agentschap voor Personen met een Handicap voor de periode 2008-2010

[Contract between the Flemish Government and the Flemish Agency for Persons with a Handicap for the period 2008-2010]; 18-1-2008. p. 1-91.

[21] Gerkens S, Merkur S. Belgium: health system review. Health Systems in Transition 2010;12:1-301.

[22] VAPH. Over het VAPH, Raadgevend Comité

[About the VAPH, Advi-sory Committee]; 2007. http://www.vaph.be/vlafo/view/nl/20896-

Raadgevend+Comite.html

[10.11.2011].

[23] Rothenburg EM. Das persönliche Budget; Eine Einfürung in Grund-lagen, Verfahren und Leistungserbringung

[The personal budget; an introduction into basic principles, process and performance]. Wein-heim und München: Juventa Verlag; 2009.

[24] Rollstuhlcheck. Kostenträger

[Who is paying for the wheelchair]. http://www.rollstuhlcheck.de/versorgungsprozess/kostentraeger

[16.5.2010, 10.11.2011].

[25] Senioren Ratgeber. Was zahlt die Krankenkasse?

[What is paid by the sickness fund?]. http://www.senioren-ratgeber.de/Besser- Leben/Was-zahlt-dieKrankenkasse-128257 2.html

[2.11.2011, 20.11.2011].

[26] Vom Hofe J. Das Persönliche Budget; 2011. http:// www.familienratgeber.de/recht/persoenliches budget.php

[30.11.2011].

[27] Rothgang H, Igl G. Long-term care in Germany. The Japanese Journal of Social Security Policy 2007;6:54-83.

[28] Keese M, Meng A, Schnabel R. Are you well prepared for long-term care? Assessing financial gaps in private German care provision, vol. 203. Bochum, Germany: Ruhr-Unversität Bochum. Ruhr Economic Papers; 2010.

[29] Ministère de la Santé et de Solidarités: Loi Handicap. Editions SICOM. Publicis Consultants; 2006. 
[30] Debout C, Lo S-H. L'allocation personnalisée d'autonomie et la presta-tion de compensation du handicap au 30 juin 2009, vol. 710. Paris, DREES: Etudes et Résultats; 2009.

[31] Fédération Nationale des Victimes de la Route. Les aides financières aux handicapés; La prestation de compensation

[Financial aid for the disabled; the compensation allowance]; 2011. http://www.fnvr-handicapindemnisation.org/ handi-cap complement allocation prestation de compensation.php

[8.11.2011].

[32] Viziroo. Qui paie pour l'APA (allocation personnalisee d'autonomie)?

[Who pays for APA

[personal allowance for independence]. http://financeslocales.over-blog.com/article-qui-paie-ml48375532.html

[10.4.2010, 21.9.2010].

[33] Bienvenue au Sénat. Projet de loi de finances pour 2008: Solidarité, insertion et égalité des chances;

2010. http://www.senat.fr/rap/a07- 095-6/a07-095-64.html

[21.9.2010].

[34] Service-Public.fr. Allocation compensatrice pour tierce personne (ACTP). http://www.senat.fr/rap/a07095-6/a07-095-64.html

[1.9.2010, 21.9.2010].

[35] Ministère des Solidarités et de la Cohésion Sociale. La commission des droits et de l'autonomie des personnes handicapées

[The com-mittee for the rights and the independence of handicapped persons].

http://www.solidarite.gouv.fr/informations-pratiques,89/fiches-pratiques,91/handicap-interlocuteurs-

et,1898/la-commission-des-droits-et-de-I,12630.html\#sommaire 1

[22.9.2011, 8.11.2011].

[36] CNSA. Le conseil de la CNSA

[The counsil of the CNSA]. Caisse nationale de solidarité pour l'autonomie des personnes âgées et des personnes handicapées. http://www.cnsa.fr/article.php3?id article=73

[6.9.2010].

[37] Mairie de Paris. Commission des Droits et de l'Autonomie des Personnes Handicapées (C.D.A.P.H.)

[Committee for the rights and the independence of handicapped persons]. 